\title{
Pumice and perlite co-substituted hydroxyapatite: Fabrication and characterization
}

\author{
Serap Gungor Koc
}

Department of Mechanical Engineering, Faculty of Engineering, Van Yuzuncu Yil University, Van, Turkey, serapgungor@yyu.edu.tr, ORCID: 0000-0002-4547-0642

\section{A B S T R A C T}

The purpose of this study was to combine hydroxyapatite (HA) with pumice and volcanic silicate perlite. Doped hydroxyapatite is inexpensive and easy to produce. A precipitation procedure was applied for synthesizing pure and doped hydroxyapatite. Samples were sintered at $1100^{\circ} \mathrm{C}$ for $1 \mathrm{~h}$. These doped structures are characterized by X-ray Diffraction (XRD), Scanning Electron Microscopy (SEM-EDS) and X-ray Fluorescence. Higher $\mathrm{SiO}_{2}$ and $\mathrm{Al}_{2} \mathrm{O}_{3}$ content was shown by XRF analysis. Nanoscale HA is obtained with density of $3.056 \mathrm{~g} / \mathrm{cm}^{3}$. The XRD results revealed the existence of the HA, $\beta$-TCP and $\mathrm{Ca}_{5}\left(\mathrm{PO}_{4}\right)_{2} \mathrm{SiO}_{4}$ phases. SEM images confirmed the sintering temperature and number of dopants had significant effect on grain sizes of the samples.

\author{
ARTICLE INFO \\ Research article \\ Received: 15.11 .2020 \\ Accepted: 21.12.2020 \\ Keywords: \\ Biomaterials, \\ pumice, \\ perlite, \\ precipitation method
}

\section{Introduction}

In recent decades, porous ceramics materials are widely used in biomedical applications. orosity provides reduced weight and widened surface area which allows better mechanical bonding with the host tissues. Hydroxyapatite (HA), $\mathrm{Ca}_{10}\left(\mathrm{PO}_{4}\right)_{6}(\mathrm{OH})_{2}$, which is in the group of calcium phosphate ceramics, considered biocompatible materials due to their ability to form strong bonds with osteogenic and hard tissues. $\mathrm{HA}$ is also used as a coating element in orthopedic and dental implants because of the structural similarities of the HA to apatite minerals in bone and tooth enamel [1-3]. Owing to the low fracture toughness and mechanical properties, HA is frequently used as a filling material in not load-bearing areas. Compressive strength and microhardness values of HA varies between $12 \mathrm{MPa}-64 \mathrm{MPa}$ and $85 \mathrm{HV}-170 \mathrm{HV}$, respectively [4]. Recently, studies were carried out to strengthen the low mechanical properties of porous $\mathrm{HA}$ and to improve its biological properties. One of these studies is doping HA with different elements [5]. In order to improve internal structure, mechanical, antibacterial and biocompatibility properties HA doped with different cations such as Ti, Y, Ag, $\mathrm{Mg}^{2+}, \mathrm{Sr}^{2+}$ and $\mathrm{Al}^{3+}$ instead of $\mathrm{Ca}$ ions in the microstructure [6,7]. Mostly, synthetic HA powders are produced by hydrothermal, precipitation, hydrolysis of calcium phosphates, or sol-gel methods. Researches revealed that the mechanical properties of HA are primarily depending on the sintering temperature and particle size. Due to the longer mixing time in the precipitation method compared to other methods, materials with smaller particle sizes $(\leq 50 \mathrm{~nm})$ produced, and therefore secondary phases not formed. The presence of secondary phases significantly reduces the mechanical strength of the material [8]. One of the methods that can be used to improve the mechanical properties of HA is doping with glassceramics obtained from silica or phosphate-based bioactive glasses. Studies revealed that composite materials strength and biocompatibility properties increased [9]. When the titanium implant is coated with silicon dioxide doped HA, the corrosion, surface roughness, and osseointegration properties increase compared to the pure HA [10].

In this study, HA has been doped separately with natural pumice and perlite. Pumice is a volcanic rock type that is porous, spongy, light, and highly resistant to atmospheric conditions. As the gases in its body leave the structure as it cools very quickly during its formation, numerous pores formed. Because of these pores, its permeability is low [4]. Pumice, which is resistant to physical and chemical factors, has a porosity ranging from $45 \%$ to $70 \%$, and its solubility in water is very low. The density of natural pumice varies between 1.2-1.4 gr/ $\mathrm{cm}^{3}$, and its compression strength varies between $1.72 \pm 0.12 \mathrm{MPa}$. The $\mathrm{pH}$ value of pumice is around seven and does not show any toxic properties [11]. In vitro tests performed on MG63 cells have shown that pumice increases the proliferation and adhesion of the cells [12]. In another study, it has been demonstrated that the biocompatibility and mechanical properties of HA, which is 
doped with $5 \%$ natural pumice by weight, compared to pure HA, have increased [13].

Perlite is a silica-based volcanic glass, and it is an amorphous, inert material with low bulk density. Perlite consists of 71$75 \%$ silicon dioxide, 12.5 to $18.0 \%$ alumina, 1 to $4 \%$ sodium and calcium oxide, and traces of metal oxide. The density of perlite, which does not show toxic properties, varies between 0.6-2.30 gm / l, and particle size around 0.2-4 mm [14]. Although, there are many studies focusing on different aspects of perlite, a few studies found on calcium phosphates. From a biomedical point of view, porous composite (ecopore) with perlite surface modified by etching, aminosilane, and combined with fibronectin showed non-toxic and promote human primary osteoblasts growth [15].

The purpose of this study is to synthesize hydroxyapatite (HA) doped with different contents of pumice and perlite to develop new nanocomposite bioceramics and to determine the optimum pumice and perlite contents which yield the best properties in terms of microstructures and mechanical properties. Pure and doped HA synthesized by a precipitation method. The synthesized materials were sintered at $1100^{\circ} \mathrm{C}$ for $1 \mathrm{~h}$. Presence of phases and bonds were characterized by x-ray diffraction (XRD). Grain sizes of the samples were obtained by scanning electron microscopy (SEM). Chemical components of the smples obtained by X-ray fluorescence (XRF).

\section{Materials and Method}

During the production of samples, HA was doped separately with pumice and perlite particles by using the precipitation method at $1 \%, 2.5 \%$, and $5 \%$ by weight. Due to the longer mixing time in the precipitation method compared to other methods, materials with smaller particle sizes $(\leq 50 \mathrm{~nm})$ are produced and therefore secondary phases are not formed. The precursor used in experimental studies were supplied from Sigma-Aldrich. In order to synthesize pure HA, precursor chemicals $\mathrm{Ca}\left(\mathrm{NO}_{3}\right) 4 \mathrm{H}_{2} \mathrm{O}$ and $\left(\mathrm{NH}_{4}\right)_{2} \mathrm{HPO}_{4}$ were separately dissolved in deionized water. $\mathrm{NH}_{4} \mathrm{OH}$ was added dropwise to the solution containing $\left(\mathrm{NH}_{4}\right)_{2} \mathrm{HPO}_{4}$ in order to $\mathrm{pH}$ value 11 . $\mathrm{NH}_{4} \mathrm{OH}$ was added in $\left(\mathrm{NH}_{4}\right)_{2} \mathrm{HPO}_{4}$ and two solutions mixed together to form one solution. The solution, which was stirred for one day at room temperature $\left(24-25^{\circ} \mathrm{C}\right)$, was left for one day for precipitation. The wet cake obtained as a result of filtering was dried at $200{ }^{\circ} \mathrm{C}$ for 12 hours and then sintered at $1100{ }^{\circ} \mathrm{C}$ for 1 hour. After drying and sintering process, pure and doped powders were ground in agate mortar. Pumice and perlite powders were added separately to the ammonium phosphate solution in the amounts indicated in Table 1.The steps used in the production of pure HA are repeated in the production of doped HA. The XRF result, main element oxide percentages (\%) of the pumice and perlite powders used in this study are given in Table 2 in terms of weight.
Table 1. The ratio of pumice and perlite added to the doped HA.

\begin{tabular}{lcc}
\hline Sample & Pumce \% mol & Perlite \% mol \\
\hline HA1.0Pumice & 1.0 & - \\
HA2.5Pumice & 2.5 & - \\
HA5.0Pumice & 5.0 & - \\
HA1.0Perlite & - & 1.0 \\
HA2.5Perlite & - & 2.5 \\
HA5.0Perlite & - & 5.0 \\
\hline
\end{tabular}

Table 2. The main oxide percentages elements of pumice and perlite powders (XRF).

\begin{tabular}{cccccccc}
\hline \multicolumn{7}{c}{ Oxides (Percentage by weight \%) } \\
\hline & $\mathrm{SiO}_{2}$ & $\mathrm{Al}_{2} \mathrm{O}_{3}$ & $\mathrm{Fe}_{2} \mathrm{O}_{3}$ & $\mathrm{CaO}$ & $\mathrm{CaCO}_{3}$ & $\mathrm{~K}_{2} \mathrm{O}$ & $\mathrm{Na}_{2} \mathrm{O}$ \\
Pumice & 74.12 & 13.12 & 1.66 & - & 6.04 & 3.82 & 1.25 \\
Perlite & 76.42 & 13.94 & 0.9 & 3.10 & - & 4.71 & 0.16 \\
\hline
\end{tabular}

XRD analysis was carried out to determine the phases in the produced powders. For this purpose, phases were determined by using a scanning speed of $2^{\circ} / \mathrm{min}$ at $10-80^{\circ} 2 \theta$ angles in a Panalytical/Empyrean device. Zeiss brand Sigma 300 device was used in SEM analysis. The chemical components of the phases in the microstructure of the powders were determined by the SEM-EDS.

\section{Result and Discussion}

$\mathrm{XRD}$ patterns of the sintered samples $\left(1100^{\circ} \mathrm{C}\right)$ were given in Figures 1-2. XRD peaks of the figure 1 consisting of the ICDD main standard peak group with the $\mathrm{HA}, \mathrm{Ca}_{5}\left(\mathrm{PO}_{4}\right)_{2} \mathrm{SiO}_{4}$ and $\beta$ TCP (ICDD:09-0432, 40-0393, 55-0898). After doping with pumice (1, 2.5 and 5 wt. \% Pu-HA) composite composed of mainly HA, with $\beta$-TCP as a secondary phase. The diffraction lines of 1, 2.5 and 5 wt. \%Pu-HA samples diminished and broadered in comporasion with pure HA. That means, 1, 2.5 and 5 wt. \%Pu-HA have smaller grain size than pure HA. 


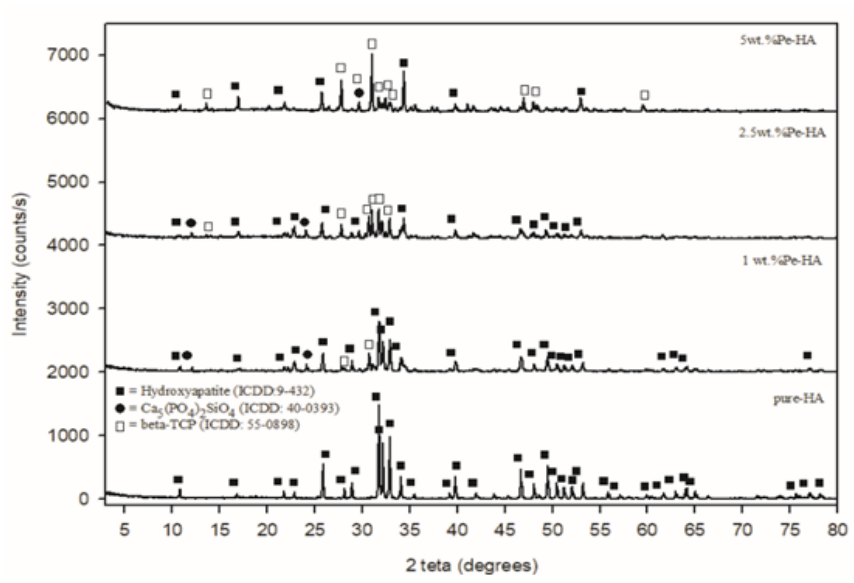

Figure 1. XRD pattern of pure-HA and pumice doped HA (1 wt. $\%, 2.5 w t . \%$ and $5 w t . \%)$.

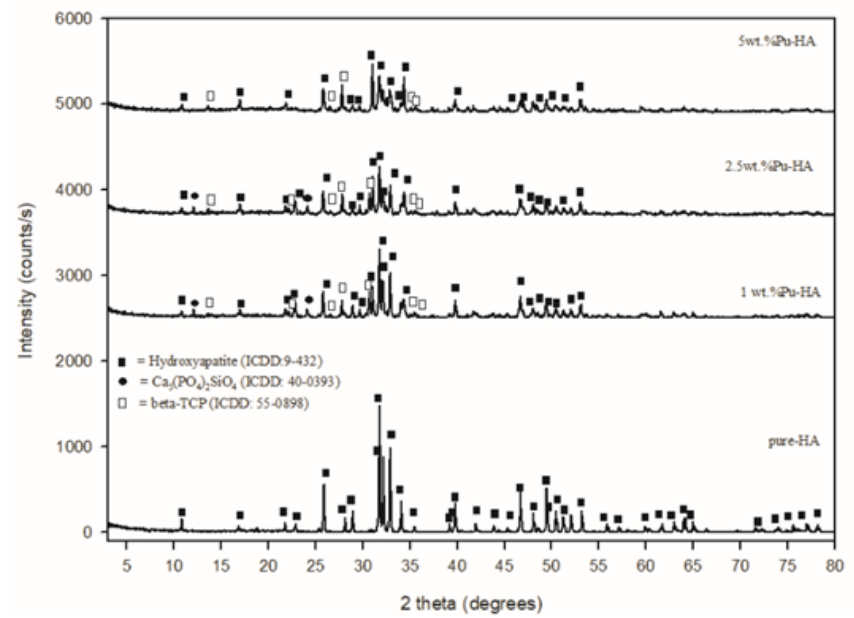

Figure 2. XRD pattern of pure-HA and perlite doped HA (1 wt. \%, 2.5wt. \% and $5 w t . \%)$.

XRD patterns of the HA doped with perlite and sintered at $1100^{\circ} \mathrm{C}$ (figure 2) are attributed to the phases of $\beta$-TCP and/or HA because peaks of $\beta$-TCP and HA are overlapping each other. In the case of $2.5 \mathrm{wt}$. \%Pe-HA and $5 \mathrm{wt}$. \%Pe-HA an increase of the $\beta$-TCP observed. Perlite addition increased the crystallinity. Due to perlite doping into peak apatite lattice, peak shift to higher $2 \theta$ values with an increase in perlite $(5 \mathrm{wt}$. $\% \mathrm{Pe}-\mathrm{HA}$ ) content. As seen from the XRD patterns peaks are attributed to $\beta$-TCP and/or HA and as a third phase $\mathrm{Ca}_{5}\left(\mathrm{PO}_{4}\right)_{2} \mathrm{SiO}_{4}$ was also observed. In the sample doped with 2.5wt. \%Pe-HA ions, most of the HA peaks transformed into $\beta$-TCP phase. Because HA, pumice and perlites different thermal expansion coefficients of the crystalline phases $(\alpha)$ may also cause high stresses at the grain boundaries and increase the thermal decomposition of the HA phases [16]. The XRD results reveals that the decomposition rate of HA depents on the mass fraction of pumice among the composites [17].
Figure 3 and figure 4 shows the surface morphology of the pure-HA, (1wt. \%-5wt. \%) Pu-HA and (1wt. \%-5wt. \%) PeHA composites, respectively. The $1 \mathrm{wt}$. \%Pu-HA, 2.5wt. \%Pu$\mathrm{HA}$ and $5 \mathrm{wt}$. \% $\mathrm{Pu}-\mathrm{HA}$ composites have porous surface with sponge-like views (Fig. 3b, c and d). When the pumice ratio increased the structure looks differs from homogeneous surface to scarce needle-shaped crystalls. The sizes of the pores seem to be increased with respect to the pure-HA.

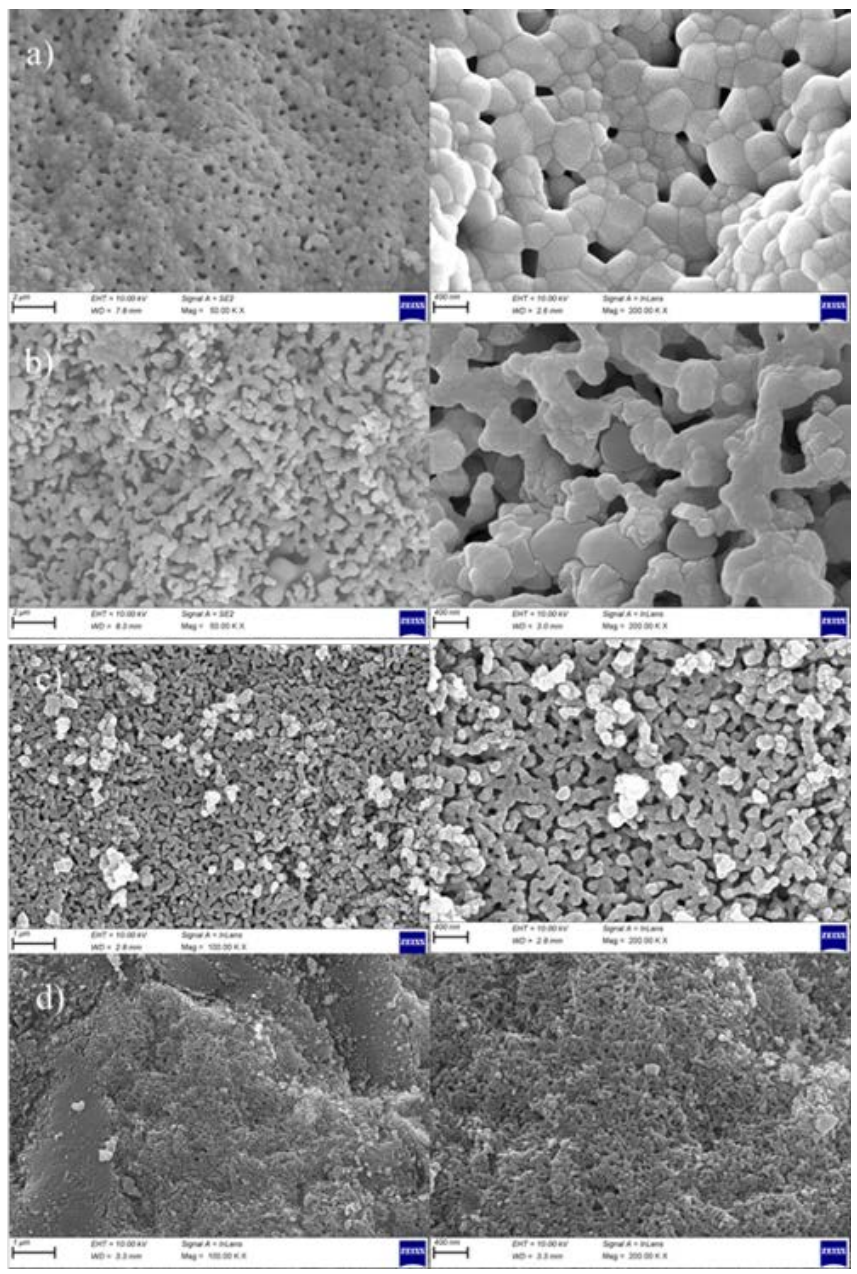

Figure 3. Scanning electron micrograph of the pure-HA (a), 1 wt. $\% \mathrm{Pu}-H A(b), 2.5 w t . \% \mathrm{Pu}-H A(c)$ and $5 w t . \% P u-H A(d)$. 


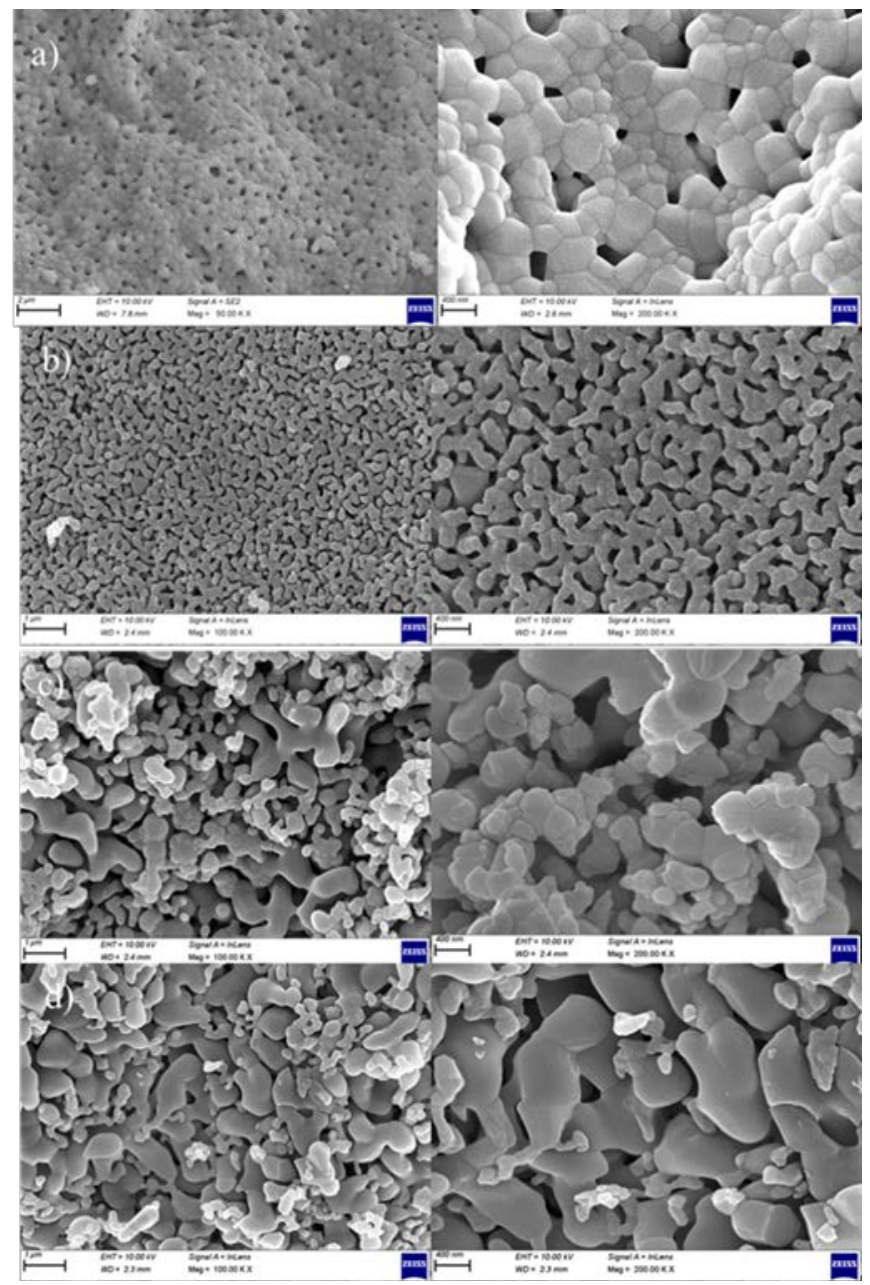

Figure 4. Scanning electron micrograph of the pure-HA (a), 1 wt. $\% \mathrm{Pe}-\mathrm{HA}(\mathrm{b}), 2.5 w t . \% \mathrm{Pe}-\mathrm{HA}$ (c) and 5wt. \%Pe-HA(d).

The changes that occurred in the grain size and morphology of HA due to the ion dopings were observed in SEM images and average grain size measurements. SEM images revealed that temperature and ion amounts of dopants had significant effect on grain sizes of the samples. There is a relationship between amount of dopant and sintering temperature with grain sizes of apatites. SEM results shows that perlite doped HA, especially, 1 wt. \%Pe-HA and 2.5wt. \%Pe-HA composites have porous surface with sponge-like views (Fig. $4 \mathrm{~b}, \mathrm{c}$ and d). In fig.4b it obvious that there are some cracks on the grains. The reason for cracks could be related to the transformation of HA into $\beta$-TCP [18].
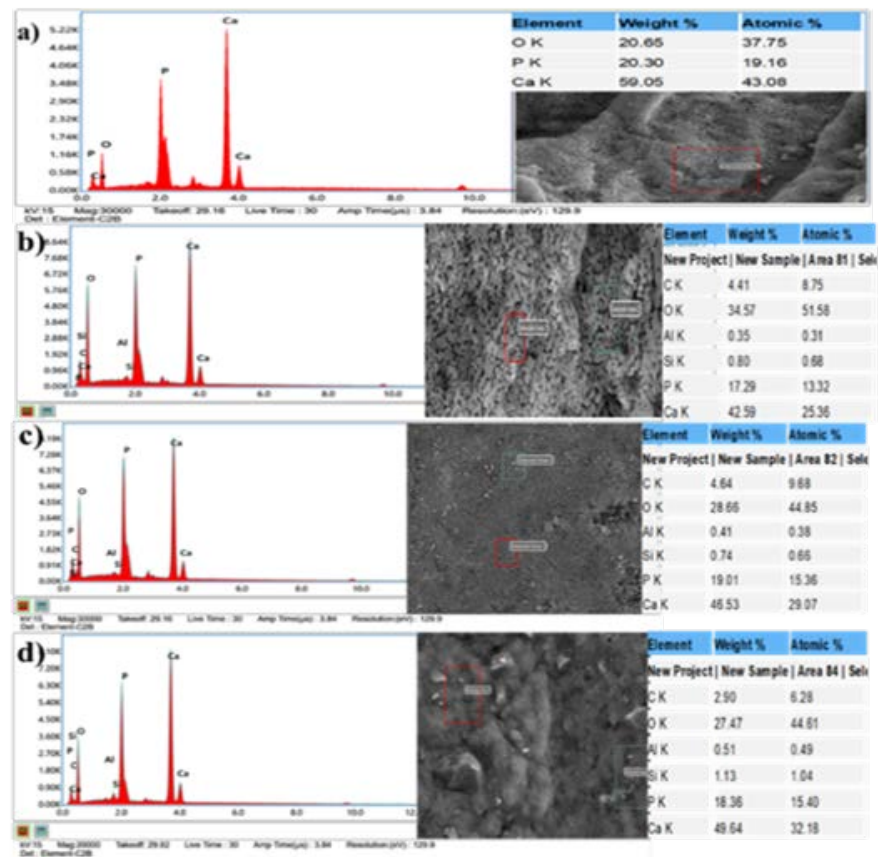

Figure 5. SEM-EDS results of the (a) pure-HA, (b) 1 wt. \%Pu-HA, (c) $2.5 w t . \% P u-H A$ and (d) $5 w t . \% P u-H A$.
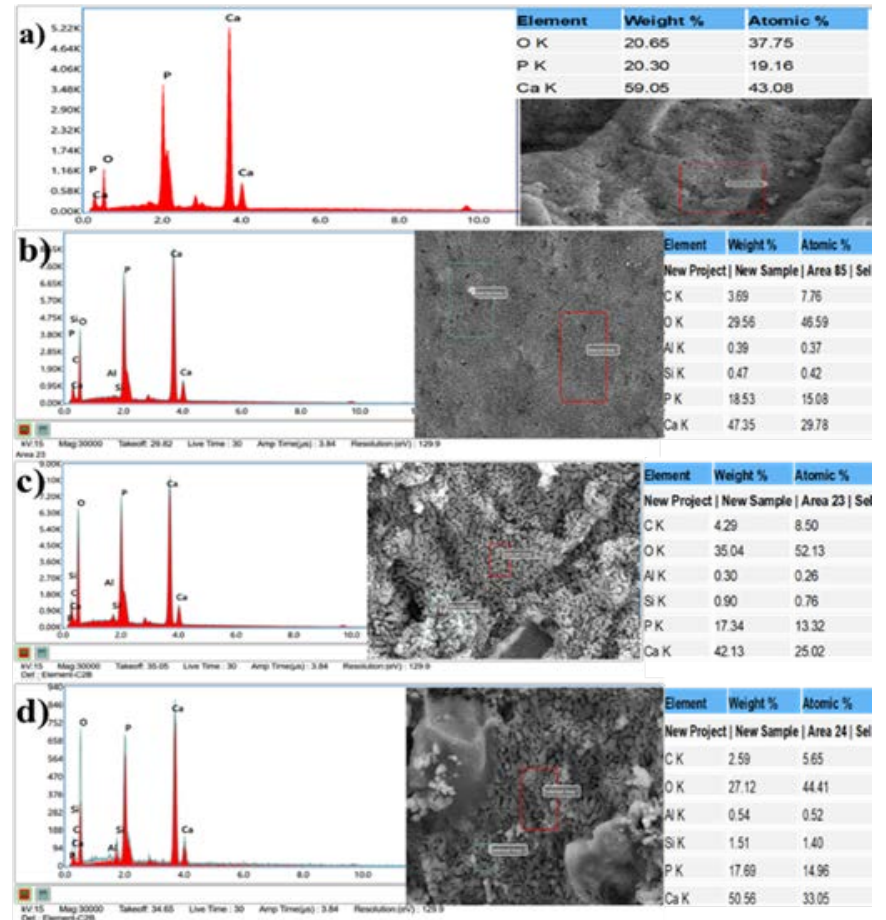

Figure 6. SEM-EDS results of the (a) pure-HA, (b) 1 wt. \%Pe-HA, (c) $2.5 w t . \% P e-H A$ and (d) $5 w t . \% P e-H A)$.

The SEM-EDS spectra along with pure-HA, Pu-HA and PeHA results were given in fig. 5 and fig. 6. Figure 5'a (pureHA) comprised of mainly Ca (43.08 at. \%), O (37.75 at. \%) and P (19.16 at. \%). In fig.5(b,c,d) pumice doped HA composed of Ca (25.36-32.18 at.\%), O (44.61-51.58 at.\%), P 
(13.32-15.40 at.\%), Si (0.66-1.04 at.\%), as well as smaller amounts of $\mathrm{Al}$ and $\mathrm{C}$.

Table 3. Density distributions of pumice and perlite doped HA.

\begin{tabular}{lc}
\hline $\begin{array}{l}\text { Sample } \\
\left(\mathbf{g} / \mathbf{c m}^{3}\right)\end{array}$ & Density \\
\hline HA & 3.056 \\
HA1.0Pumice & 2.778 \\
HA2.5Pumice & 2.727 \\
HA5.0Pumice & 2.565 \\
HA1.0Perlite & 2.578 \\
HA2.5Perlite & 2.282 \\
HA5.0Perlite & 2.031 \\
\hline
\end{tabular}

Several studies have been conducted to determine the density of HA. According to literature, the density of HA varies between 3.05-3.1 $\mathrm{g} / \mathrm{cm}^{3}$. In those studies, the density of nanoscale HA is about $3.056 \mathrm{~g} / \mathrm{cm}^{3}$ this results are compatible with our results $\left(3.056 \mathrm{~g} / \mathrm{cm}^{3}\right)$. The lowest density among the doped samples were HA5.0Pumice and HA5.0Perlite which in combination with second phases in SEM results (Table 3) [19].

\section{Conclusion}

In this study, HA doped with pumice and perlite were synthesized by a precipitation method. Doping amount of pumice and perlite were kept at 1.0-5.0 wt.\%. All samples were sintered at $1100^{\circ} \mathrm{C}$ for $1 \mathrm{~h}$. Microstructural and mechanical properties of the sintered samples were investigated via XRD, SEM-EDS and XRF methods. XRD patterns peaks are attributed to $\beta$-TCP and/or HA and as a third phase $\mathrm{Ca}_{5}\left(\mathrm{PO}_{4}\right)_{2} \mathrm{SiO}_{4}$ was observed.The diffraction lines of 1 , 2.5 and $5 \mathrm{wt}$. \%Pu-HA samples diminished and broadered in comporasion with pure HA. That means, $1,2.5$ and 5 wt. \%PuHA have smaller grain size than pure HA. In this study, $\mathrm{Pu}-$ $\mathrm{HA}$ and Pe-HA non-toxic composites revealed a remarkable potential for biomedical applications as coating element and bone graft.

\section{References}

[1]. Dorozhkin S.V., "Calcium orthophosphate-containing biocomposites and hybrid biomaterials for biomedical applications", Journal of Functional Biomaterials, 6, (2015), 708-832.

[2]. Gervaso F., Scalera F., Padmanabhan S.K., Sannino A., Licciulli A., "High performance hydroxyapatite scaffolds for bone tissue engineering applications",
International Journal of Applied Ceramics Technolgy, 9, (2012), 507-516.

[3]. Ciobanu G., Ilisei S., Luca C., Carja G., Ciobanu O., "The effect of vitamins to hydroxyapatite growth on porous polyurethane substrate", Progress in Organic Coating, 74, (2012), 648-653.

[4]. Gündüz, L., Yılmaz, İ., 1998. Orta Anadolu Pomza Oluşumlarının Endüstriyel Olarak Kullanılabilirlik Ölçütleri. 4. Endüstriyel Hammaddeler Sempozyumu 118-19 Ekim 2001, İzmir, TÜRKIYE, 214-215.

[5]. Ciobanu G., Bargan A.M., Luca C., "New bismuthsubstituted hydroxyapatite nanoparticles for bone tissue engineering”, JOM, 67, (2015), 2534-2542.

[6]. Tahmasebifar A., Gungor S., Evis Z., "The microstructural investigation of nano- calcium phosphates doped with fluoride ions". Journal of the Faculty of Engineering and Architecture of Gazi University, 30, (2015), 1-7.

[7]. Koc G. S., "Synthesis and characterization of strontium and chlorine co-doped tricalcium phosphate". Materials Letters, 248, (2019),69-72.

[8]. Ahn, E.S., Gleason, N.J., Nakahira, A. ve Ying, J.Y., "Nanostructure processing of hydroxyapatite-based bioceramics”, Nano Letters, 1, (2001), 149-153.

[9]. Georgiou G., Knowles J.C., “Glass reinforced hydroxyapatite for hard tissue surgery- part 1 : mechanical properties”, Biomaterials, 22, (2001), 28115.

[10]. Bohur B.G., "HVOF Tekniğiyle Ti6Al4V Metal Altlık Yüzeyine Farklı Silika Kaynağı İçeren Biyoseramiklerin Kaplanması", Yüksek Lisans Tezi, Afyon Kocatepe Üniversitesi, Fen Bilimleri Enstitüsü, (2018).

[11]. Kılınç-Aksay, E., 2005. İzmir-Menderes Yöresi Pomza Cevherinin Kullanımına Yönelik Teknolojik Özelliklerinin Araştırılması, Dokuz Eylül Üniversitesi Fen Bilimleri Enstitüsü Doktora Tezi, 6-7.

[12]. Li X., Yang W., Zou Q., Zou Y., “Investigation on microstructure, composition, and cytocompatibility of natürel pumice for potential biomedical application”, Tissue Engineering Part C, 16-3, (2010), 427-34.

[13]. Komur B., Lohse T., Can H.M., Khalilova G., Geçimli Z.N., Aydoğdu M.O., Kalkandelen C., Stan G.E., Sahin Y.M., Sengil A.Z., Suleymanoglu M., Kuruca S.E., 
Oktar F.N., Salman S., Ekren N., Ficai A., Gundez O., "Fabrication of naturel pumice/hydroxyapatite composite for biomedical engineering”. BioMedical Engineering, (2016), 15:81.

[14]. Samar M., Saxena S., "Study of chemical and physical properties of perlite and its apllications in India", International Journal of Science Technology and Management, 5:4, (2016), 70-80,

[15]. Walter von M at. al. "In vitro behavior of a porous TiO2/perlite composite and its surface modification with fibronectin’. Biomaterials, (2005), 26, 2813-2826.

[16]. Yang C., Guo Y.K., Zhang M.L., “Thermal decomposition and mechanical properties of hydroxyapatite ceramic”. Transactions Nonferrous Metals Society China. 20, (2010), 254-8.

[17]. Komur B. et. al. "Fabrication of naturel pumice/hydroxyapatite composite for biomedical engineering”, BioMedical Engineering, (2016), 15, 81.

[18]. Mestres G., Le Van C., Ginebra M.P., "Siliconstabilized $\alpha$-tricalcium phosphate and its use in a calcium phosphate cement: characterization and cell response”. Acta Biomaterials, 8(3), (2012), 1169-79.

[19]. Wu Y., Bose S. "Nano crystalline hydroxyapatie: Micelle templated synthesis and characterization”. ACS Publications, 21, (2005), 3232-3234. 